\title{
Research on Development Countermeasures of the Micro Courses Construction in Colleges and Universities
}

\author{
Jiyuan Feng ${ }^{1}$ and Shengbin Zhao ${ }^{1, *}$ \\ ${ }^{1}$ Shenyang Jianzhu University, Shenyang, China \\ * The Corresponding Author
}

\begin{abstract}
Keywords: Micro Course; Universities; Development Countermeasures
\end{abstract}
\begin{abstract}
With the development of information technology, people's lives are becoming more and more applications, and some digital products have become an important part of our lives, All walks of life gradually moving towards the information technology, China's education is a typical, and one of the new teaching resources - micro course is an important manifestation of educational information. In recent years, it has been applied in the field of education in our country, but its development speed is very fast, and it is only a few years in the country to promote and apply to the major colleges and universities. there are a lot of problem on the current situation of the construction of micro courses in Colleges and Universities, this paper analyzed and discussed these problem and gave corresponding development countermeasures, to a certain extent, it also promotes the smooth development and continuous improvement of the micro course construction in Colleges and universities, then let the micro lesson in the future teaching better promote students learning, but also can help teachers to better carry out teaching work, improve teaching quality.
\end{abstract}

\section{Introduction}

Micro course is a new concept for our country teaching area, which originated abroad, with the development of Electronic Science and technology in recent years, more and more people pay close attention to the teaching mode of micro class, which has also been widespread concern in China. Micro course educational model, is a new teaching model after the impact of information technology which use internet and media to realize the Combination of the online education and interactive education, using the convenient and combining the education goal with short online video mode to realize the online learning without time and place. micro course plays a more and more important role in our teaching system. On this basis, this paper will further discuss micro class resources in the current situation of the construction of our country, points out the problems which exist in the micro class, at the same time for the development of micro class scientific and rational countermeasures.

\section{Micro Course Summary}

Definition. In foreign countries, the definition of micro course refers to: Through a novel idea, the micro course realizes online learning or mobile learning by using network technology, which is not limited by time and space and has a clear teaching content or teaching purposes to realize one minute teaching course with audio or video. Micro courses can not only achieve online teaching, distance learning and other models, but also can provide students with more learning video, students can learn anytime, anywhere, free from location and time constraints. At present, there is no clear definition of the definition of "micro course" in our country.

At present, there is no clear definition of the definition of "micro course" in our country. If it is literally understood, "micro" in Chinese characters represent the "small, slight" meaning. Course is generally related to teaching. Therefore, it can be seen that the micro course is to achieve teaching activities in a limited time. Domestic scholar Zhang Yichun, interpreted micro course: Domestic scholar Zhang Yichun, will be interpreted as a micro course: it uses the network technology and digital products, for those who wish to acquire knowledge through their active learning, focuses on 
the teaching content of a knowledge point of elaborate design, which is mainly through the mode of video and audio. The domestic Hu Tiesheng, pioneered the concept of micro course for the definition of "micro course": using the video as a carrier of knowledge to achieve a brief teaching links. Generally speaking, micro course is small course. Micro course is specifically class or course, domestic scholars Jinling gave a definition asthat micro course is to realize the communication between curriculum and learning, students and Curriculum and Can effectively link its various links, record the classroom teaching record. So micro course is an important part of micro lesson.

Main Characters. Micro course is made of small video with only one minute which has following three main characters: firstly, short and pithy, extensive use, easy communication, the time of video concept is usually short and smaller storage, usually with between ten and twenty trillion Smaller for a few trillion, in the aspect of micro course concept, it is usually difficult to be understood for students but also have certain teaching value. These videos are elaborately designed by teachers with rich teaching experience which can satisfy student's need. This part of the content can not only be used as a teacher in the teaching of the classroom to explain the key content, but also can be used as a preview of students learning materials. Secondly, the theme is prominent, targeted, easy to use. The focus of the micro course is micro word above, usually after the selection of a certain knowledge points, the knowledge points will be subdivided, so as to further highlight the theme, to solve the problem, In this way to help the majority of the use of micro download video viewer to master the knowledge according to their needs, this way of learning, not only saves the time of the majority of learners, but also improves their learning efficiency, to provide convenience for the majority of users. Thirdly, semi structured, interactive strong, easy to expand. In the aspect of making and training courseware micro combining the relative static knowledge points with the practical teaching of the course, to achieve the interaction between teachers and students, teachers and students exchanges, and further use of the network platform to achieve reprint, modify and further improve, In the process of building a flexible structure of the formation of the 1.5 micro structured resources and application framework, this kind of micro course has the characteristics of semi-structured, interactive, open, generative and flexible.

\section{Analysis on the Present Situation of the Construction of Micro Course Resources in Colleges and Universities}

In recent years, the development of information technology to benefit from all walks of life, efficient teaching is no exception, in the new situation, the environment, the development of micro course resources have been developed. the practice at home and abroad shows that the course can effectively improve the teaching quality and efficiency. However, the development of micro course in our country is short, and there are still many problems in the construction of micro course resources, which mainly includes the following three aspects.

Lack of Awareness of the Necessity of the Construction of Micro Course Resources in Colleges and Universities. With the development of micro courses in foreign countries, our country has also carried on the micro class teaching in the university teaching, which can enhance the University own social appraisal, the influence as well as attracts more students. At present, most of the colleges and universities in our country pay much attention to the development of the micro courses educational resources, and carry out the related educational activities, academic and scientific research exchanges. But at this stage, the depth of application of micro courses is not optimistic, many colleges and universities do not attach importance to the construction of micro course resources, and thus can not play the advantages of micro courses. The students are the most authoritative speakers of the current situation of the construction of micro course resources, according to the relevant student survey report, it shows that many students generally don't need micro class resources construction has many deficiencies, the micro teaching resources of the most dispersed and can not meet the learning needs of students. As colleges and universities, they should attach importance to the construction of micro teaching resources, the teaching resources of micro courses in the same important position. 
The Actual Effect of the Use of Micro Courses is Poor. At present, the micro course is still at the beginning stage in our country's education, so its practical application effect is not ideal. According to the relevant data show, at present, nearly half of the teachers in Colleges and universities do not apply micro courses in their own teaching, and more than $1 / 2$ of the students are skeptical about this new teaching mode. Teachers are the development of micro courses, but the teachers who have excellent teaching skills are only $1 / 10$ of the total number of teachers, at the same time, although there are some micro teaching team in Colleges and universities, but in terms of the size, the team is also very limited. Based on the above situation, there are still many problems in the construction of micro course resources in Colleges and universities in our country, which is an important problem to be solved.

Lack of Proper Use of Micro Platform. The development of information technology in recent years is obvious to people, therefore our life has undergone tremendous change, many universities have established campus teaching resources platform of their own, this is undoubtedly a good thing for the majority of teachers and students. But the platform is not a micro teaching platform in most colleges and universities, so they cannot do the sharing of micro course information, which will not be able to use micro courses. At the same time, the poor integration of the current micro course resources, results in uneven quality of various courses in Colleges and universities, and the total amount of micro course resources is still very lacking, which makes it difficult to apply the limited micro course resources to the actual teaching, thus greatly affecting the construction of micro course resources. At the same time,

\section{Construction and Practice of Micro Course Resources in Colleges and Universities}

The Depth Understanding of the Construction of Micro Course. Due to the continuous improvement of information technology, micro courses have emerged. Its appearance is to realize the student's fragmented learning and mobile learning, to stimulate students' interest in autonomous learning, through zhis model to renew self knowledge structure. Due to the difference of everyone's understaning, the effects of micro course are not the same.in terms of the understanding of micro course, There are mainly two aspects namely "micro" and "class", the former refering to the time is short, the cost in commonly 10 minutes . In such a short time, it is impossible to explain everything, but the focus is limited to a single point of knowledge or focus, difficulties; The latter refers to a kind of classroom teaching, which is a kind of teaching course. the content of Micro class is more extensive and its model is for students, which can give students more time to participate in the classroom teaching, students' interaction in teaching, so as to enhance the efficiency of classroom teaching.

If want to do a good job in the construction of micro class resources, it is necessary to fully understand the importance of their ideas, and then by the relevant departments to coordinate closely, the unified plan the construction of micro courses in Colleges and universities. In the course of the construction of micro resources in Colleges and universities, we should fully realize that this is a step by step process, in the funding, policy, regulation, technology and other aspects of the introduction that need a strong support. At the same time in order to prevent the development of chaos, it is necessary to establish and improve the construction of the University of micro course system, unify planning and implementation

To Build a Good Platform For the Application of Micro Course Resources to Achieve Resource Sharing. If want to do a good job in the construction of micro class resources, we should take full account of the sharing of micro teaching resources, and this problem is achieved through the use of specialized micro course resources practical application platform. At present, most colleges and universities do not have such a platform, and the sharing of micro course resources is only relying on micro teaching competition platform to implement, which cannot achieve the purpose of resource sharing. Therefore, in view of the construction of this area, by selecting a central school, and spread to form a circle, the effective realization of resource sharing. Through this flexible platform, students can learn independently, in this platform, teachers and students can continue to improve and improve the corresponding curriculum content, give full play to the 
dominant position of students which can promote the interaction between teachers and students, for some difficult problems, it is also possible to get a thorough understanding and solution through a flexible subject discussion, thus making teaching more efficient.

Multi Collaborative, Using a Variety of Models to Promote the Construction of Micro Courses. A complete micro teaching platform involves a wide range of content, not only the teaching design, teaching content and teaching technology, etc. These contents can not be completed solely by the teachers, must rely on multi forces to complete together. There are two main methods to promote the teaching resources of the course. One is based on the original micro course resources, through the construction and improvement of the content of the library, the method has the advantages of fast construction speed, but it is due to the establishment of the original micro course resource library, which leads to the improvement of the overall level of resources; The other is are self subject according to the teaching requirements, followed by the corresponding teaching objectives and a series of content to analyze. According to the content of the textbook, then through the corresponding multimedia technology processing and recording to achieve a new micro course resource, this way can improve the overall quality of the micro course, but it consumes more manpower and material resources, the development cycle is relatively long. Therefore, combined with the advantages and disadvantages of both, the advantages and disadvantages of the construction of the micro course resources can be used reasonably.

To Achieve a Systematic and Specialized Course. According to the survey, the majority of colleges and universities in our country have not yet perfected the micro course resources of various subjects, which is not systemic and professional. Therefore, it is necessary to strengthen the construction of the discipline of micro course resources, to form a perfect micro course system, only in this way can the comprehensive service teaching, improve students' learning efficiency.

\section{Conclusion}

To sum up, the development of micro courses in China today, in its development there is indeed a problem, especially the micro class construction, we need to combine their own teaching experience, to find and solve problems in practice. In this paper, the current situation of the construction of micro courses, this paper analyzes the existing problems and puts forward some practical countermeasures, Only in this way can we make it better to promote students' learning in the future teaching, and also help teachers make better use of learning resources to do their own teaching work.

\section{References}

[1] Yu Shengquan, Chen Min. Design of micro course based on learning meta platform [J].Open education research. 2014 (01)

[2] Hu Tiesheng. The difficulties in the construction and application of micro courses in primary and secondary schools $[\mathrm{J}]$. Information technology education in primary and secondary schools. $2013(04)$

[3] Hu Tiesheng. The development and thinking of regional high quality micro course resources [J]. Information technology education in primary and secondary schools. 2013 (04)

[4] Liang Leming, Cao Qiao Qiao, Zhang Baohui. Study on the model of micro curriculum design: Based on the comparative analysis of micro courses at home and abroad [J]. open education research. 2013 (01)

[5] Hu Tiesheng, Zhan Chunqing. The regional practice and Enlightenment of the development of high quality micro course resources in primary and secondary schools [J]. China education information. 2012 (22) 
[6] Fan Fulan, Zhang Yi, Bai L, Lin Li. Analysis of the application effect of the teaching model based on interactive micro video teaching resources [J]. modern educational technology. 2012 (06)

[7] Hu Tiesheng, Huang Mingyan, Li Min. Three stages of the development of micro course in China and Its Enlightenment [J]. Journal of distance education. 2013 (04)

[8] Liu Hongxia, Zhao Yu,Chen Lei. Design and practice of teaching behavior based on the characteristics of "micro course" [J]. modern educational technology. 2014 (02)

[9] Lu Haiyan. Feasibility analysis of the application of "flipped classroom" model in College English teaching [J].Foreign language teaching.2014 (04)

[10] Quine. Understanding and practice of regional digital educational resources construction and application [J]. China education information. 2009 (18) 